\title{
QUARTZ MEGACRYSTS IN GREECE: MINERALOGY AND ENVIRONMENT OF FORMATION
}

\author{
Maneta V. ${ }^{1}$ and Voudouris P. ${ }^{1}$ \\ ${ }^{1}$ University of Athens, Department of Geology \& Geoenvironment, Section of Mineralogy \& Petrology, \\ 15784 Athens, Greece,victoriageol@yahoo.gr,voudouris@geol.uoa.gr
}

\begin{abstract}
Quartz megacrysts in Greece are systematically sampled, described and classified with respect to their morphology, solid inclusion mineralogy, and geological conditions of formation. Quartz deposition took place due to reduction in silica solubility in the hydrothermal fluids in favourable geological environments such as: alpine-type fissures close to major detachment faults, skarns and quartz veins crosscutting and generally related to granitoids and, finally, epithermally altered volcanic rocks of Tertiary age. The varieties of coloured crystals (amethyst, smoky quartz, morion, green quartz, rock crystal), the twinning of the crystals, the mineralogy of solid phases included in quartz (rutile, chlorite, sericite, feldspars) as well as the types and forms of the crystals (Tessin habit, Muzo habit, faden quartz, sceptre, window quartz, interrupted crystals, double-terminated crystals, phantom quartz, gwindel quartz, etc.) give important information on the growth mechanisms and the physico-chemical conditions during quartz formation. The quartz crystals found in several localities are gemmy and their potential for use as gemstones should be evaluated.
\end{abstract}

Key words: quartz, megacrysts, habits, solid inclusions, gemstones.

\section{Introduction}

Quartz is formed in several geological environments and it is considered as one of the most common minerals in nature. The different conditions, namely the pressure and temperature that characterise each environment, determine which type of $\mathrm{SiO}_{2}$ mineral will be formed in every case. Moreover, the type and often the habit of the crystals, the accessory minerals, as well as the solid inclusions they contain provide useful information regarding the environment of formation (Rykart, 1995; Dibble, 2002). This paper will focus on quartz crystals formed in three different geological environments: the alpine-type fissures encountered in metamorphic rocks, environments related to granitoids of Tertiary age and volcanic-hosted epithermal environments.

The first group contains quartz crystals which are formed in greenschist phase metamorphic conditions. During the ascend of metamorphic rocks to the surface extensive fissures are formed in shear zones and several minerals, including quartz, are deposited due to the decrease in pressure and temperature. These fissures are usually elongated or sigmoidal, they develop perpendicular to the schistosity of the rock and crosscut the major structural elements of the Alpine compressive deformation.

The second group includes quartz crystals encountered in miarolithic cavities or quartz veins developed in granitoids and pegmatites of Tertiary age. It also contains quartz crystals found at contact metamorphic zones, where skarns are formed. In this case quartz is a typical mineral of the 
retrograde stage.

The third group contains quartz crystals found in veins in volcanic rocks of Tertiary age, mainly lavas of intermediate or acidic composition as well as pyroclastic rocks. In this case the deposition of quartz is related to the development of hydrothermal and geothermal systems during the last stages of Tertiary volcanism.

\section{Geological setting}

The Hellenides constitute part of the Alpine-Himalayan orogen and formed when Apulia collided with Europe in Late Cretaceous to Tertiary. The Hellenides are subdivided in several units: the Rhodope Massif, the Servo-Macedonian Massif, the Vardar Zone, the Pelagonian Zone and the Attico-Cycladic Massif (Internal Hellenides) and the External Hellenides built up by Mesozoic and Cenozoic rocks (Dürr et al., 1978; Jacobshagen, 1986). New data suggest that the Hellenides can be considered an accretionary orogen, where a late Precambrian to late Jurassic evolution was marked by the opening and closure of ocean basins and continental crust formation in the accompanying subduction zones (Himmerkus et al., 2006; Reischmann \& Kostopoulos, 2007). A Permo-Carboniferous igneous event (known from the Pelagonian Zone, the Rhodope Massif and the Attico-Cycladic Zone) documents an active continental margin evolution in the Precambrian-Silurian basement of the Hellenides. After the closure of the Vardar Ocean, shortening and syn-orogenic exhumation of HP-LT rocks occurred during the late Cretaceous-Eocene, before an acceleration of slab retreat changed the subduction regime and caused the collapse of the Hellenic mountain belt and the thinning of the Aegean Sea from the middle Eocene/late Oligocene to the present (Jolivet et al., 2004). During this post-orogenic episode large-scale detachments formed, which exhumed metamorphic core complexes in a back-arc setting (Cyclades and Rhodope). Tertiary magmatism in the Aegean region occurred mostly in a post-collisional setting behind the active Hellenic subduction zone. The Cenozoic magmatic activity, considered to be associated with the Cretaceous to Miocene AlpineBalkan-Carpathian-Dinaride orogen, resulted from underthrusting of the African plate beneath the Eurasian plate (Pe-Piper \& Piper, 2002). This magmatic event took place after the closure of the last remnants of the Tethys Ocean (Pindos, Vardar-Izmir-Ankara and Intra-Pontide branches) and the collision of the continental blocks of Apulia, Pelagonia and Rhodope with continental Europe. The Pliocene to recent volcanic rocks in the active Aegean volcanic arc seem to have formed as a consequence of active subduction beneath the Hellenic trench.

\section{Analytical methods}

Twenty-four thin and polished thin sections of quartz crystals with solid inclusions were studied with an optical microscope and a JEOL JSM 5600 scanning electron microscope equipped with back-scattered imaging capabilities, at the Department of Mineralogy and Petrology, University of Athens, Greece. Analytical methods also included X-powder diffraction measurements obtained using a SIEMENS type D-500 diffractometer with $\mathrm{Cu}$ tube and Co filter at the Department of Mineralogy and Petrology, University of Athens, Greece.

\section{Geological environments of formation}

\subsection{Alpine-type fissures}

In the northern part of Greece alpine-type fissures are encountered in various metamorphic rocks that belong to the Rhodope-Servomacedonian massif (Papanikolaou \& Panagopoulos, 1981; Mposkos 


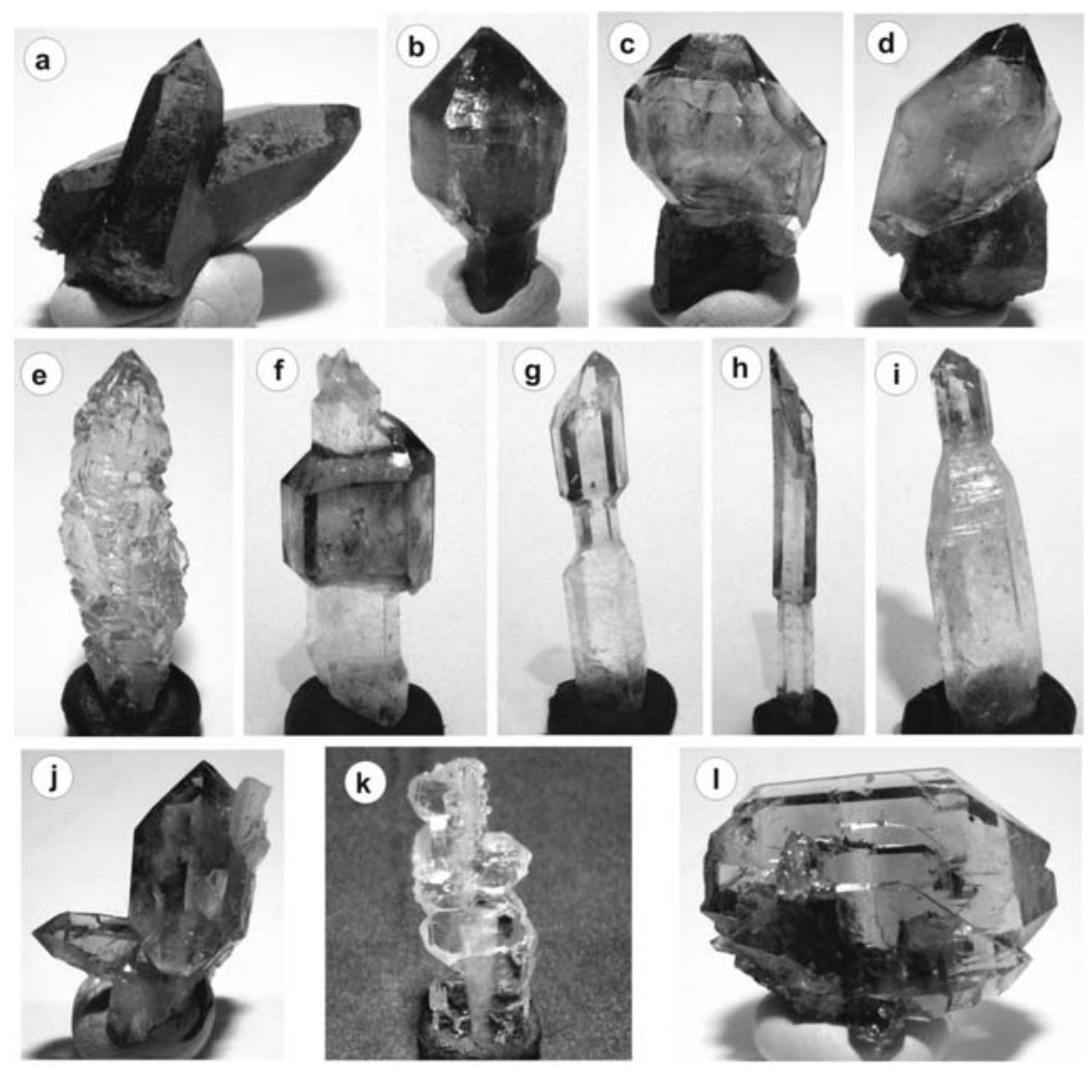

Fig. 1: Quartz crystals from alpine-type fissures (dimensions refer to photo width). (a) Tessin smoky quartz crystals, Dasoto (8cm); (b-d) Amethyst prismatic sceptres on smoky quartz, Dasoto (4cm); (e) Colourless eroded Tessin quartz crystal, Thassos (4cm); (f, g) Triple prismatic quartz sceptres, Thassos (4cm); (h) Prismatic smoky quartz sceptre on prismatic colourless quartz, Thassos $(4 \mathrm{~cm})$; (i) Prismatic smoky quartz inverse sceptre on prismatic transitional colourless quartz, Thassos (3cm); (j) Smoky quartz, Krieza-Koskina (5cm); (k) Faden colourless quartz, Karystos (3cm); (1) Gwindel smoky quartz, Stamata (5cm).

\& Krohe, 2001). Quartz crystals have been found in three sites, near the village of Dasoto in Drama, on the island of Thassos and in Sithonia on the Chalkidiki peninsula. In Dasoto quartz is found in veins in Paleozoic orthogneisses. In these veins the crystals are deposited on a massive milky to black quartz matrix. Morion, smoky or colourless quartz crystals often develop the Tessin habit, whereas normal or inverse sceptres with prismatic amethyst on top are also found (Voudouris et al., 2004a; Melfos, 2005) (Fig. 1a-d). Amethyst in these sceptres can sometimes develop window structures. On Thassos Island quartz crystals are deposited in fissures within metapegmatites, orthogneisses, paragneisses, amphibolites and marbles (Wawrzenitz \& Krohe, 1998). The most impressive forms of quartz crystals in this area are the triple sceptres encountered in parageneisses (Voudouris, 2005) (Fig. 1f-i). The base of the sceptres consists of Tessin crystals, often with eroded faces (Fig. 1e), while the first generation is colourless prismatic quartz. The second sceptre is window smoky quartz with Dauphiné habit and the third generation is represented by colourless crystals. Colourless prismatic quartz crystals which form inverse sceptres are also found in the area as well as single Tessin smoky or colourless crystals. Quartz in amphibolites usually forms colourless 
or amethyst Tessin single crystals. In Sithonia dark smoky quartz crystals with Tessin habit accompanied by feldspar are found in sigmoidal fissures that have been developed in the granite and the pegmatites of the area.

In the Attico-Cycladic massif quartz can be encountered in many areas (Voudouris et al., 2004a; Tsolakos et al., 2008). The Krieza-Koskina area in Evia (central Greece) consists of schists, marbles, amphibolites and orthogeneisses (Katzir et al., 2000; Shaked et al., 2000). Quartz crystals have been formed in quartz veins which usually fill sigmoidal fissures or in seggregations that consist of quartz and feldspar. A wide variety of crystal forms can be found in the area: typical prismatic crystals, gwindel crystals, quartz crystals with chlorite phantoms, faden quartz and flattened crystal forms. The crystals are transparent and can be colourless or smoky (Fig. 1j). In Karystos (southern Evia) prismatic quartz crystals and colourless faden forms (Fig. 1k) are encountered in orthogneisses and amphibolites. In Attica (central Greece) quartz crystals are found in three areas, namely Stamata, Marathonas and Mt. Penteli. All three areas consist of orthogneisses and marbles (Lozios, 1993) which are crosscut by quartz veins that fill alpine-type fissures. The Stamata area is characterised by the same mineralogy and crystal habits (Fig. 11) that have already been described in Krieza-Koskina. In Marathonas and the mountain of Penteli the fissures are filled with parallel quartz veins in which prismatic quartz crystals as big as $50 \mathrm{~cm}$ have been found. Window structures are often developed on the faces of some colourless prismatic crystals, while cathedral quartz forms, crystals with chlorite phantoms and dark smoky quartz crystals are also present in the area. However, the most typical crystals encountered are the normal and inverse sceptres that consist of rock crystal, smoky quartz or amethyst. On Seriphos Island milky Tessin quartz crystals were deposited in extensional sigmoidal fissures developed in the Seriphos leucogranite (Iglseder et al., 2009). On the island of Ios colourless and smoky (close to morion) prismatic quartz crystals have been deposited in quartz veins in orthogneisses (Henjes-Kunst \& Kreuzer, 1982), where smoky quartz sceptres are also found. Sericite often develops phantoms in quartz crystals, while chlorite can form solid inclusions in smoky quartz.

\subsection{Environments related to Tertiary granitoids}

In the Rhodope massif quartz crystals are found in many areas, namely Vrontou, Kimmeria, Maronia, the island of Samothraki, and Stratoni on the Chalkidiki peninsula. In Vrontou quartz crystals have been deposited in multiple quartz veins that crosscut the andraditic skarn developed at the contact zone between the Vrontou plutonite and the marbles of the area. Quartz crystals with chlorite phantoms and Dauphiné habit are present. In Kimmeria quartz crystals are found in the Xanthi granodiorite, as well as in the skarn that is formed at the contact zone between the plutonite and the metamorphic rocks of the area (gneisses, amphibolites and marbles) (Liati, 1986). In quartz veins that crosscut the plutonite colourless and milky Tessin quartz crystals can be found (Fig. 2a). At the contact zone quartz crystals are deposited in the exoskarn and their formation is related to the development of quartz veins in the andraditic and wollastonitic skarns of the area. The typical prismatic forms can be found in these sites as well as peculiar needle-like crystals with Dauphiné habits (Fig. 2c). The most impressive form of quartz crystals in Kimmeria is the typical flattened Japan-law twins that are found together with the previously mentioned needle-like Dauphiné crystals (Fig. 2b) (Voudouris \& Katerinopoulos, 2004). In Maronia quartz is encountered in the granitoids of the area (granite and porphyritic microgranite) (Melfos et al., 2002). In the microgranite colourless Tessin crystals are developed in milky quartz veins that crosscut the granitoid. In the granite transitional Tessin to prismatic milky to light brown quartz crystals are deposited in miarolithic cavities. On the island of Samothraki milky prismatic and Tessin quartz crystals are found in veins that crosscut the granite of Samothraki. On the Chalkidiki peninsula quartz is encountered near the village of Stra- 


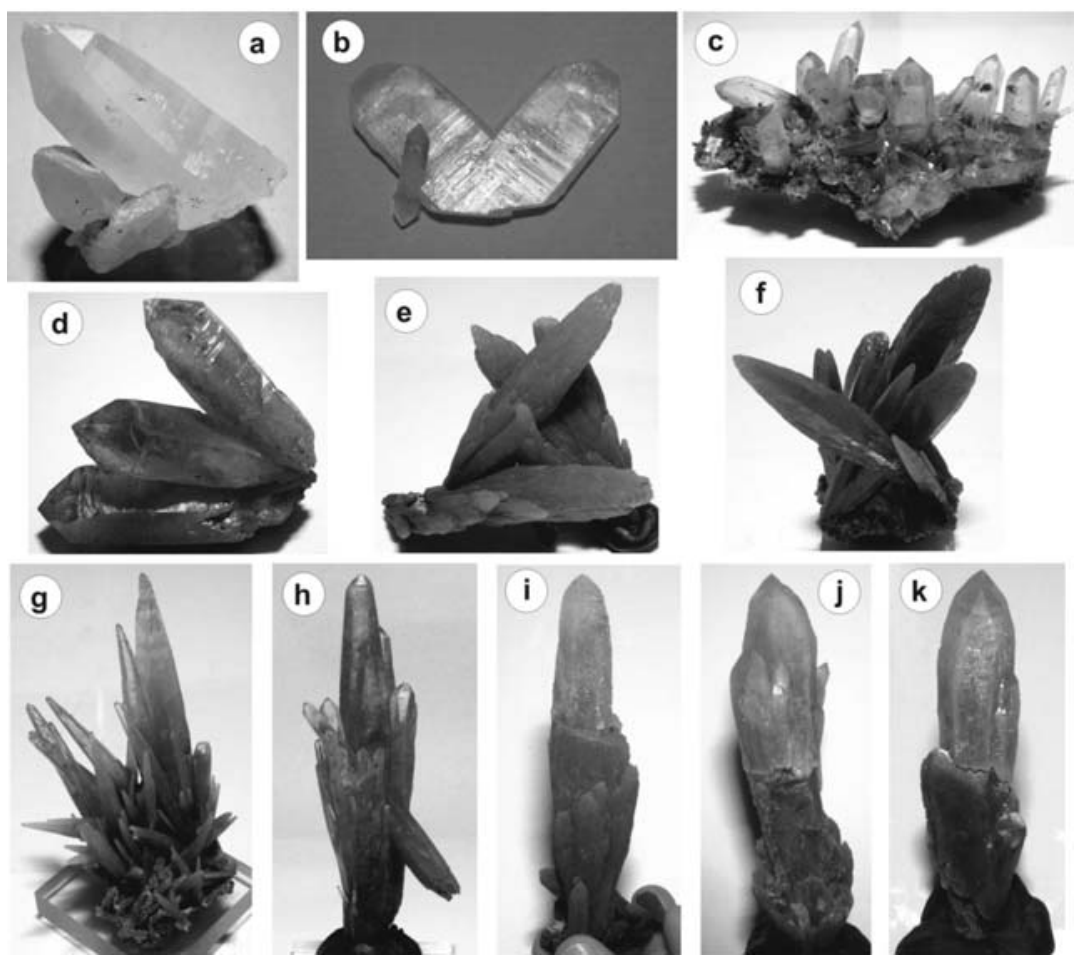

Fig. 2: Quartz crystals from environments related to Tertiary granitoids (dimensions refer to photo width). (a) Tessin colourless quartz, Kimmeria (6cm); (b) Japan-law twin quartz crystals, Kimmeria (5cm); (c) Prismatic and Dauphiné quartz crystals, Kimmeria, $(7 \mathrm{~cm})$; (d) Prismatic and Dauphiné smoky quartz crystals, Lavrio $(10 \mathrm{~cm}) ;(\mathrm{e}, \mathrm{f})$ Spindle-like green quartz crystals, Seriphos $(10 \mathrm{~cm}$ and $12 \mathrm{~cm}$ respectively); $(\mathrm{g}, \mathrm{h})$ Amethystgreen quartz crystals, Seriphos ( $7 \mathrm{~cm}$ and $5 \mathrm{~cm}$ respectively); (i-k) Normal and inverse amethyst sceptres on green quartz, Seriphos $(6 \mathrm{~cm})$.

toni. In the carbonate-replacement $\mathrm{Pb}-\mathrm{Zn}$-Au deposit of Stratoni gneisses and marbles are crosscut by quartz veins that include typical prismatic quartz crystals, colourless or milky transitional crystals and rarely sceptres (up to $60 \mathrm{~cm}$ ).

In the Attico-Cycladic massif quartz is found in three areas, namely Lavrio (Attica) and on the islands of Tinos and Seriphos. In the carbonate-replacement deposit of Lavrio quartz forms milky and more rarely brown prismatic crystals (Fig. 2d), crystals with rocket habit or trigonal and bundle forms, whereas in some cases large quartz crystals (up to $20 \mathrm{~cm}$ ) are often surrounded by multiple smaller ones (Voudouris et al., 2004b). On Tinos Island prismatic and Tessin smoky quartz crystals have been deposited, together with spessartine and orthoclase, in miarolithic cavities in the Tertiary leucogranite of the area (Mastrakas, 2006). On Seriphos Island quartz crystals were formed in geodes developed in quartz veins that crosscut the granatitic and hedenbergitic skarn at the contact zone of the granodiorite and the gneisses (Salemink, 1980). The form of the crystals is prismatic with a trigonal top and the colour is usually milky or green (actinolite inclusions), whereas amethyst sometimes constitutes the base of inverse sceptres with colourless tops. Locally the hedenbergite is crosscut by veins of green quartz where the famous Seriphos spindle-like quartz crystals are deposited (Gauthier \& Albandakis, 1991) (Fig. 2e, f). The crystals are usually green quartz or amethyst or a 
combination of the two (Fig. $2 \mathrm{~g}, \mathrm{~h}$ ). Their form might also change from a typical spindle-like base to a hexagonal amethyst top. Prismatic green quartz crystals are also found as well as rocket forms with amethyst in the base and green quartz on top. The sceptres found in the area are normal or inverse with green quartz in the base and an often trigonal amethyst top (Fig. 2i-k). An unusual type of crystals encountered in the area is the interrupted green or amethyst quartz crystals which are formed when flattened calcite crystals are deposited together with quartz in successive layers (Voudouris et al., 2007).

\subsection{Volcanic-hosted epithermal environments}

In northern Greece quartz crystals are found in many sites that represent epithermally altered volcanic environments, namely Kornofolia, Sapes and Kirki (Melfos 2005). In Kornofolia hydrothermal fluids have deposited short hexagonal prismatic amethyst crystals, colourless quartz crystals and chalcedony in veins in the Tertiary dacitic lavas of the area. In Sapes quartz and chalcedony were deposited in veins developed in pyroclastic rocks and andesitic/dacitic lavas. Colourless quartz sceptres with trigonal tops and window structures on the faces are found, while hexagonal prismatic amethyst crystals are rare. The latter are usually developed on a smoky quartz base. In Kirki chalcedony veins crosscut the submarine dacitic lavas of the area. In cavities in the central part of the veins short amethyst and colourless quartz crystals are formed.

In the northern Aegean island of Lesvos the Miocene lavas (Pe-Piper \& Piper, 2002) are crosscut by veins where prismatic amethyst crystals and sceptres are encountered (Voudouris \& Katerinopoulos, 2004) (Fig. a-d). Window structures are observed on the faces of the sceptres, the top part of which has developed Muzo and Cipo habits. Large colourless crystals with Muzo habit have also been found in the area. In another site pink quartz forms stalagmitic structures which are covered with small pink quartz crystals (Fig. 3e).

In the Attico-Cycladic massif the island of Milos represents a volcanic-hosted epithermal environment where rhyodacitic lavas and pyroclastic materials of Plio-Pleistocene age are crosscut by chalcedony and amethyst veins. In these veins short prismatic amethyst and colourless quartz crystals have been deposited (Alfieris, 2006).

\section{Solid inclusions in quartz}

A significant number of minerals are encountered as solid inclusions in quartz crystals. Their presence is often directly related to the colour of the crystals and provides valuable information regarding the physico-chemical conditions that characterised the geological environment where quartz crystals were formed.

Actinolite is encountered in alpine fissures (Fig. 4a, b) and skarns as needle-like green crystals that form solid inclusions in quartz. Its presence in the skarn of Seriphos is particularly significant, since it gives quartz (prase) the characteristic green colour.

Calcite is found together with quartz in environments related to Tertiary granitoids (Seriphos skarn), where it is responsible for the development of interrupted quartz crystals. However, its presence is more usually associated with volcanic environments where tabular calcite crystals accompany chalcedony, quartz and amethyst in geodes.

Chlorite is encountered in numerous areas in all three types of geological environments mentioned in the previous section. Chlorite is particularly common in alpine-type fissures where it forms solid 

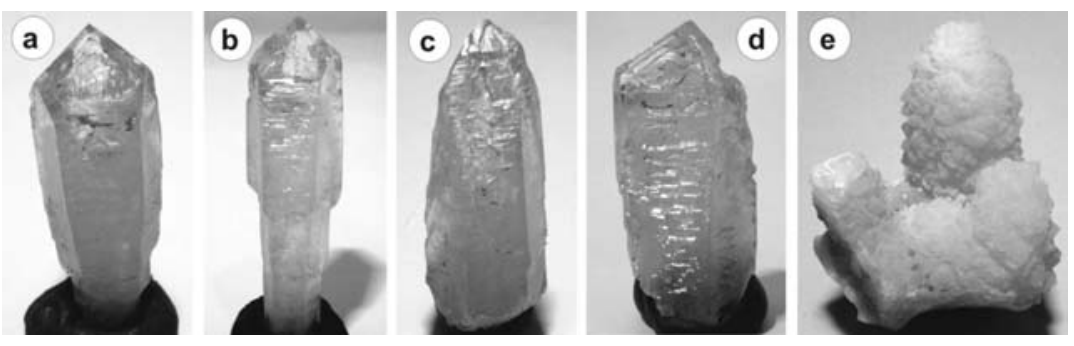

Fig. 3: Quartz crystals from volcanic-hosted epithermal environments (dimensions refer to photo width). (a, b) Trigonal amethyst sceptres that develop window structures, Lesvos ( $3 \mathrm{~cm}$ and $4 \mathrm{~cm}$ respectively); (c) Amethyst with Muzo habit and window structures, Lesvos (4cm); (d) Trigonal amethyst with window structures, Lesvos (4cm); (e) Stalagmitic pink quartz, Lesvos (6cm).

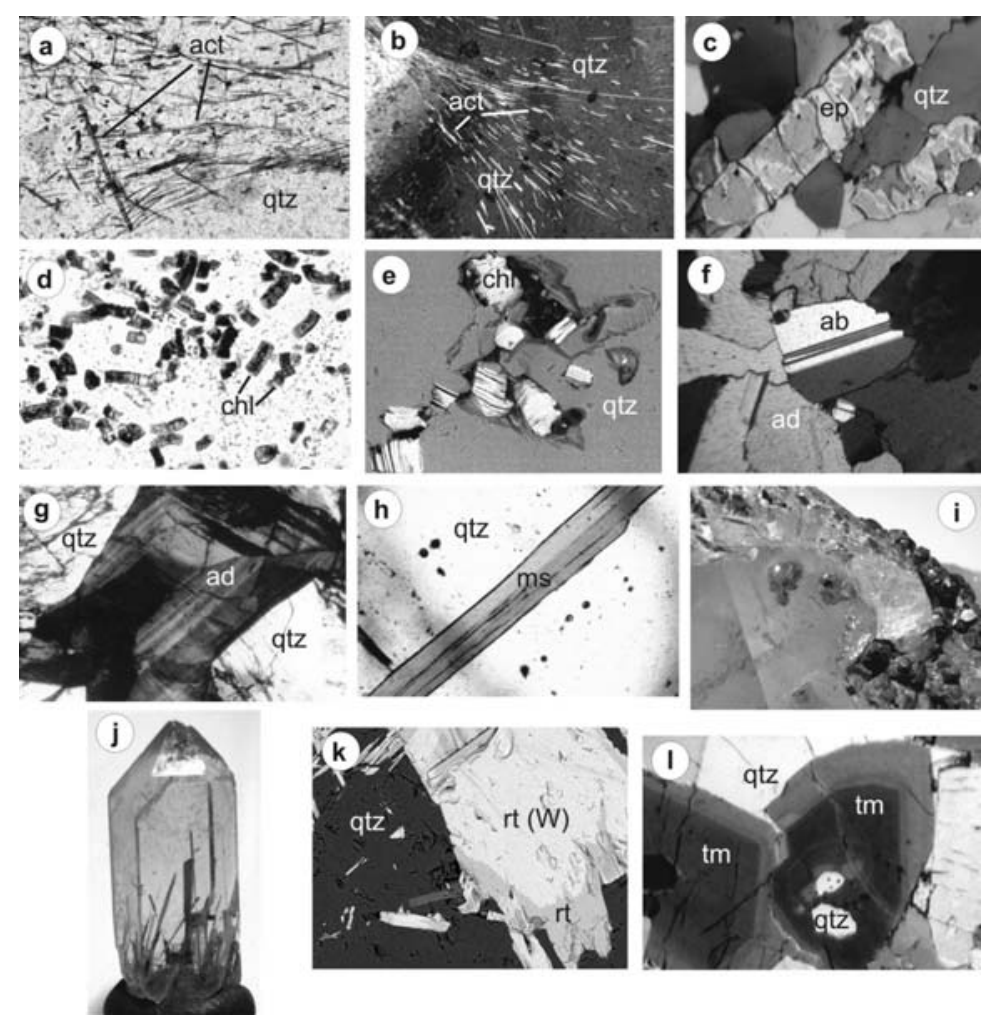

Fig. 4: Solid inclusions in quartz (dimensions refer to photo width). (a, b) Polarising microscope images (//nicols and +nicols respectively) of needle-like actinolite (act) in quartz (qtz), Karystos ( $0.12 \mathrm{~mm}$ and $1 \mathrm{~mm}$ respectively); (c) Polarising microscope image (+nicols) of Mn-rich epidote (ep) together with quartz (qtz), Thassos (0.6mm); (d) Polarising microscope image (//nicols) of chlorite (chl) in quartz, Krieza-Koskina (0.12mm); (e) SEM image of chlorite (chl) in quartz (qtz), Krieza-Koskina (0.35mm); (f) Polarising microscope image (+nicols) of albite (ab) and adularia (ad), Krieza-Koskina (1mm); (g) Polarising microscope image (+nicols) of zoned adularia (ad) together with amethyst (qtz), Sappes (1 mm); (h) Polarising microscope image (+nicols) of muscovite (ms) in smoky quartz (qtz), Thassos $(0.6 \mathrm{~mm})$. i) Pyrite in quartz, Crete $(3 \mathrm{~cm})$; (j) Red rutile crystals in quartz, Krieza-Koskina $(3 \mathrm{~cm})$; (k) SEM image of rutile (rt) with a W-rich core (rt (W)) in quartz (qtz), Penteli (0.3mm); (l) Polarising microscope image (//nicols) of zoned tourmaline $(\mathrm{tm})$ together with quartz (qtz), Thassos, $(0.6 \mathrm{~mm})$. 
inclusions in quartz crystals (Fig. 4d, e) and is often responsible for the green colour of quartz as well as the development of phantom quartz crystals. Idiomorphic pseudo-hexagonal chlorite crystals have been found on Thassos where they accompany rutile and quartz in fissures. In the skarn of Vrontou chlorite forms phantoms in quartz, whereas in Kimmeria it covers the faces of the crystals. In volcanic-hosted epithermal environments chlorite usually forms microscopic inclusions in quartz crystals. Representative microprobe analyses of studied chlorites are included in Table 1. All chlorites are classified as Fe-clinochlores. Based on the geothermometer of Cathelineau (1988) the formation temperatures of the studied chlorites vary from $228^{\circ}$ to $310^{\circ} \mathrm{C}$ (Table 1$)$.

Epidote is found together with quartz in all three types of environments mentioned above. Dark pink Mn-rich epidote accompanies and is included in milky and smoky quartz crystals found in alpinetype fissures on Thassos (Fig. 4c). In other areas where alpine-type fissures occur epidote forms

Table 1. Representative microprobe analyses of chlorite

\begin{tabular}{|l|r|r|r|r|r|r|r|r|r|r|}
\hline $\mathrm{Wt} . \%$ & 1 & 2 & 3 & 4 & 5 & 6 & 7 & 8 & 9 & 10 \\
\hline $\mathrm{SiO}_{2}$ & 27.85 & 27.37 & 28.40 & 28.43 & 30.87 & 30.39 & 31.50 & 29.31 & 28.92 & 29.12 \\
\hline $\mathrm{Al}_{2} \mathrm{O}_{3}$ & 19.21 & 18.21 & 19.47 & 19.91 & 17.51 & 18.43 & 19.65 & 18.36 & 19.81 & 19.61 \\
\hline $\mathrm{TiO}_{2}$ & bd & bd & bd & bd & 0.11 & bd & bd & bd & 0.03 & bd \\
\hline $\mathrm{FeO}$ & 23.94 & 25.32 & 23.78 & 18.34 & 22.20 & 19.84 & 19.81 & 14.23 & 15.03 & 14.59 \\
\hline $\mathrm{MnO}$ & 0.31 & 0.37 & 0.38 & 0.38 & 0.68 & 0.42 & 0.39 & 0.65 & 0.84 & 0.74 \\
\hline $\mathrm{MgO}$ & 17.12 & 17.05 & 18.16 & 21.47 & 17.75 & 16.99 & 17.83 & 23.37 & 22.90 & 23.55 \\
\hline $\mathrm{CaO}$ & bd & bd & 0.05 & bd & 0.34 & 0.37 & 0.45 & 0.06 & 0.10 & 0.07 \\
\hline $\mathrm{Na} 2 \mathrm{O}$ & 0.31 & 0.46 & 0.46 & 0.11 & 0.70 & 0.66 & 0.65 & 0.08 & 0.02 & 0.03 \\
\hline $\mathrm{K}_{2} \mathrm{O}$ & bd & 0.03 & 0.02 & bd & 0.09 & 0.15 & 0.19 & 0.03 & 0.01 & 0.01 \\
\hline $\mathrm{Total}$ & 88.74 & 88.82 & 90.72 & 88.64 & 90.81 & 88.14 & 90.52 & 86.09 & 87.66 & 87.72 \\
\hline & & & $\mathrm{Cations}$ on the basis of $28(\mathrm{O})$ & & & & \\
\hline $\mathrm{Si}$ & 5.752 & 5.701 & 5.714 & 5.693 & 6.160 & 6.195 & 6.195 & 5.929 & 5.769 & 5.786 \\
\hline $\mathrm{Al}$ & 4.670 & 4.480 & 4.620 & 4.699 & 4.130 & 4.445 & 4.550 & 4.377 & 4.657 & 4.593 \\
\hline $\mathrm{Ti}$ & - & - & - & - & 0.000 & - & - & - & 0.000 & - \\
\hline $\mathrm{Fe}$ & 4.136 & 4.416 & 4.009 & 3.071 & 3.710 & 3.395 & 3.255 & 2.407 & 2.506 & 2.425 \\
\hline $\mathrm{Mn}$ & 0.050 & 0.063 & 0.063 & 0.064 & 0.105 & 0.070 & 0.070 & 0.111 & 0.141 & 0.125 \\
\hline $\mathrm{Mg}$ & 5.269 & 5.294 & 5.447 & 6.409 & 5.285 & 5.180 & 5.215 & 7.047 & 6.808 & 6.974 \\
\hline $\mathrm{Ca}$ & - & - & 0.012 & - & 0.070 & 0.070 & 0.105 & 0.014 & 0.021 & 0.015 \\
\hline $\mathrm{Na}$ & 0.127 & 0.190 & 0.178 & 0.043 & 0.280 & 0.245 & 0.245 & 0.000 & 0.000 & 0.000 \\
\hline $\mathrm{K}$ & - & 0.012 & 0.000 & - & 0.035 & 0.035 & 0.035 & 0.000 & 0.000 & 0.000 \\
\hline $\mathrm{T}{ }^{\circ} \mathrm{C}$ & & & & & & & & & & \\
$\mathrm{Cathelineau}$ & 300.0 & 308.1 & 306.1 & 310.0 & 234.3 & 227.9 & 227.9 & 271.5 & 297.2 & 294.5 \\
\hline 1988$)$ & & & & & & & & & & \\
\hline
\end{tabular}

1-3: Krieza-Koskina (Evia), 4: Ios, 5-7: Lesvos, 8-10: Sapes (Rhodope) 
needle-like green crystals in colourless prismatic quartz. In environments associated with granitoids dark green epidote crystals are encountered as inclusions in quartz. On Lesvos Island epidote accompanies amethyst in the lavas.

Feldspars are found as accessory minerals and solid inclusions in quartz crystals in all three types of geological environments that were mentioned in the previous section. In the alpine-type fissures of Evia adularia forms pseudo-rhombohedral milky or green crystals, whereas albite develops idiomorphic colourless crystals that form Manebach and albite-law twins (Fig. 4f). Milky adularia crystals that often form Manebach twins are also found on the island of Thassos. In Maronia orthoclase forms milky crystals, whereas in Samothraki pink orthoclase crystals up to $5 \mathrm{~cm}$ are found. Milky adularia crystals up to $2 \mathrm{~cm}$ are encountered in the skarns of Vrontou and Kimmeria. The presence of feldspars is particularly significant in the amethyst veins of Sapes where zoned adularia crystals form solid inclusions and also accompany quartz (Fig. 4g).

Fluorite accompanies quartz in the carbonate-replacement deposits of Lavrio and amethyst in the veins that crosscut the lavas in Lesvos.

Garnet forms small orange crystals (spessartine) that accompany quartz in the alpine-type fissures of Thassos. However, their presence is more important in environments related to Tertiary granitoids, especially in skarns. On Tinos Island spessartine accompanies quartz in miarolithic cavities in the leucogranite of the area, whereas on Seriphos Island andradite is found together with quartz in geodes in the granatitic and hedenbergitic skarn.

Hematite is encountered together with quartz in alpine-type fissures where it develops aggregations of hexagonal tabular black crystals that resemble the form of a rose or, more often, small tabular crystals as inclusions in quartz. Tabular hematite crystals are also found in environments related to Tetriary granitoids.

Muscovite and sericite are quite common as solid inclusions in quartz crystals. In alpine-type fissures on Thassos muscovite forms idiomorphic pseudo-hexagonal crystals that accompany rock crystal and smoky quartz (Fig. 4h). On Ios muscovite creates phantoms in quartz crystals, whereas in Penteli it forms thin tabular crystals in quartz. In environments related to granitoids muscovite is also common as an inclusion in quartz in many areas. Regarding the volcanic environments the most interesting site is Sappes where muscovite forms small inclusions in amethyst crystals.

Rutile is encountered as an inclusion in quartz crystals in many areas where alpine-type fissures have been developed. In Penteli needle-like dark brown to black rutile crystals are found as inclusions in quartz (Fig. 4k), while prismatic tetragonal rutile crystals accompany quartz in fissures in the same area. In Dasoto, Krieza-Koskina (Fig. 4j) and Thassos rutile accompanies quartz and forms needle-like crystals with golden, reddish and dark red colour respectively. In Karystos rutile forms misroscopic inclusions in quartz together with albite and zircon. Rutile was also found in Kimmeria in microscopic inclusions together with muscovite and monazite in the quartz veins that crosscut the granodiorite. Table 2 contains representative microprobe analyses of rutile from Penteli, Karystos and Kimmeria. The rutiles from Penteli and Kimmeria display chemical zoning, where the cores are enriched in $\mathrm{WO}_{3}$ (up to 4.84 wt. \% and $3.11 \mathrm{wt}$. \% respectively), and the rims are $\mathrm{WO}_{3}$ free ( $<0.65$ wt. \% in Penteli and $<0.24$ wt. \% in Kimmeria) (Fig. 4k). $\mathrm{Nb}_{2} \mathrm{O}_{5}$ (up to 3.41 wt. \% in Pendeli rutiles) and $\mathrm{SnO}_{2}$ (up to 0.5 wt. \% in Kimmeria) were also detected (Table 2).

Various sulphide minerals are found as accessory minerals and solid inclusions in quartz in all three types of geological environments. In alpine-type fissures pyrite can form quite large crystals in colourless quartz (Fig. 4i). The presence of sulphide minerals is more important in environments related to 
Tertiary granitoids where galena, pyrite, sphalerite, bismuthinite and molybdainite are found as solid inclusions in quartz or as accessory minerals. Regarding the volcanic environments, sulphide minerals are only found in the area of Kirki where pyrite accompanies quartz in chalcedony veins.

Tourmaline is encountered together with quartz, hematite and chlorite in the alpine-type fissures of Thassos Island where it forms needle-like black crystals (Fig. 4l).

Wollastonite is found in environments associated with granitoids where it accompanies quartz crystals (Maronia) or forms the base of the veins where the Japan-law twin quartz crystals were deposited (Kimmeria).

Table 2. Representative microprobe analyses of rutile.

\begin{tabular}{|c|c|c|c|c|c|c|c|c|c|}
\hline Wt. \% & 1 & 2 & 3 & 4 & 5 & 6 & 7 & 8 & 9 \\
\hline $\mathrm{SiO}_{2}$ & $\mathrm{bd}$ & 0.30 & 0.05 & 0.14 & 0.77 & 0.17 & 0.32 & 0.29 & 0.05 \\
\hline $\mathrm{Al}_{2} \mathrm{O}_{3}$ & 0.07 & 0.05 & 0.03 & 0.05 & 0.12 & 0.17 & 0.03 & 0.10 & bd \\
\hline $\mathrm{TiO}_{2}$ & 91.66 & 96.93 & 99.25 & 88.02 & 97.53 & 95.06 & 98.72 & 95.41 & 95.60 \\
\hline $\mathrm{Fe}_{2} \mathrm{O}_{3}$ & 3.09 & 1.03 & 0.63 & 3.52 & 0.40 & 1.84 & 0.67 & 1.64 & 1.19 \\
\hline $\mathrm{MnO}$ & bd & bd & 0.11 & $\mathrm{bd}$ & 0.19 & bd & bd & bd & bd \\
\hline $\mathrm{MgO}$ & $\mathrm{bd}$ & $\mathrm{bd}$ & $\mathrm{bd}$ & $\mathrm{bd}$ & 0.13 & $\mathrm{bd}$ & bd & bd & bd \\
\hline $\mathrm{CaO}$ & bd & bd & bd & bd & 0.87 & bd & bd & bd & bd \\
\hline $\mathrm{Na}_{2} \mathrm{O}$ & bd & bd & bd & bd & 0.05 & bd & bd & bd & bd \\
\hline $\mathrm{Cr}_{2} \mathrm{O}_{3}$ & 0.02 & 0.08 & 0.04 & 0.03 & $\mathrm{bd}$ & 0.31 & 0.11 & bd & 0.47 \\
\hline $\mathrm{Nb}_{2} \mathrm{O} 5$ & 0.85 & 0.27 & 0.21 & 3.41 & bd & bd & bd & bd & bd \\
\hline $\mathrm{SnO}_{2}$ & bd & 0.24 & $\mathrm{bd}$ & bd & bd & 0.11 & 0.48 & 0.14 & bd \\
\hline $\mathrm{WO}_{3}$ & 4.81 & 0.65 & 0.47 & 4.84 & bd & 3.11 & 0.24 & 2.56 & 3.00 \\
\hline Total & 100.50 & 99.55 & 100.79 & 100.01 & 100.06 & 100.77 & 100.57 & 100.14 & 100.31 \\
\hline \multicolumn{10}{|c|}{ Cations on the basis of $2(\mathrm{O})$} \\
\hline $\mathrm{Si}$ & - & 0.004 & 0.001 & 0.002 & 0.010 & 0.002 & 0.004 & 0.004 & 0.001 \\
\hline $\mathrm{Al}$ & 0.001 & 0.001 & 0.000 & 0.001 & 0.002 & 0.003 & 0.000 & 0.001 & - \\
\hline $\mathrm{Ti}$ & 0.956 & 0.970 & 0.994 & 0.928 & 0.977 & 0.961 & 0.987 & 0.965 & 0.958 \\
\hline $\mathrm{Fe}$ & 0.032 & 0.010 & 0.006 & 0.037 & 0.005 & 0.019 & 0.006 & 0.016 & 0.011 \\
\hline $\mathrm{Mn}$ & - & - & 0.001 & - & 0.002 & - & - & - & - \\
\hline $\mathrm{Mg}$ & - & - & - & - & 0.002 & - & - & - & - \\
\hline $\mathrm{Ca}$ & - & - & - & - & 0.013 & - & - & - & - \\
\hline $\mathrm{Na}$ & - & - & - & - & 0.001 & - & - & - & - \\
\hline $\mathrm{Cr}$ & 0.000 & 0.001 & 0.000 & 0.000 & - & 0.003 & 0.002 & - & 0.005 \\
\hline $\mathrm{Nb}$ & 0.005 & 0.002 & 0.001 & 0.022 & - & - & - & - & - \\
\hline $\mathrm{Sn}$ & - & 0.001 & - & - & - & 0.001 & 0.002 & 0.001 & - \\
\hline $\mathrm{W}$ & 0.017 & 0.002 & 0.002 & 0.018 & - & 0.011 & 0.001 & 0.009 & 0.010 \\
\hline
\end{tabular}

1-4: Penteli (Attica), 5: Karystos (Evia), 6-9: Kimmeria (Xanthi). 


\section{Conclusions}

Quartz is encountered in many areas in Greece where it develops a variety of habits and forms. The colour of quartz as well as the minerals that form solid inclusions in the crystals and the accessory minerals that accompany quartz are determined by the lithology of the parent rocks. Therefore, the type of crystal that is formed in each site reflects the conditions that prevail in the environment where quartz is formed. In this paper three main geological environments of formation have been distinguished, namely the alpine-type fissures, the environments related to Tertiary granitoids and the volcanic-hosted epithermal environments. Some quartz crystals found in various areas are of gem quality and their potential for use as gemstones should be evaluated. Such is the case of the amethyst in Dasoto, the colourless quartz crystals from Thassos Island, the smoky quartz from Krieza-Koskina, the quartz crystals with needle-like rutile solid inclusions in the area of Penteli, the green quartz and amethyst crystals from Seriphos Island and the amethyst in Kornofolia, Sapes, Lesvos and Milos. Moreover, numerous sites contain rare quartz crystals which should be preserved in mineralogical geotopes. Such is the case of Dasoto, Thassos, Evia, the area of Penteli, Kimmeria, Maronia, Samothraki Island, Lavrio, Seriphos Island, Kornofolia, Sapes, and the islands of Lesvos and Milos. Lastly, other sites can serve an educational purpose since they clearly reflect the results of geological activity in the area, like the different generations of sceptres that are found on Thassos, which represent the different stages in the emergence of the Rhodope massif, the skarns in Kimmeria and Seriphos and the epithermal environments of Sapes, Lesvos and Milos. These sites should also be preserved since they represent parts of the geological heritage of Greece.

\section{References}

Alfieris, D., 2006. Geological, geochemical and mineralogical studies of shallow submarine epithermal mineralization in an emergent volcanic edifice, at Milos island (western side), Greece. PhD thesis, Univ. Hamburg, 211pp.

Altherr, R., Kreuzer, H., Wendt, I., Lenz, H., Wagner, G., Keller, J., Harre, W., and Hohndorf, A., 1982. A late Oligocene/Early Miocene High Temperature Belt in the Attic-Cycladic Crystalline Complex (SE Pelagonian, Greece). Geol. Jb., 23, 97-164.

Cathelineau, M., 1988. Cation size occupancy in chlorites and illites as a function of temperature. Clay Mineral 23, 471-485.

Dibble, H.L., 2002. Quartz: An introduction to crystalline quartz. Dibble Trust Fund Publ. NY USA, 100pp.

Dür, S.T., Altherr R., Keller J., Okrusch M., and Seidel, E., 1978. The median Aegean crysralline belt: Stratigraphy, Structure, Meramorphism, Magmatism. In Alps, Apennines, Hellenides, 455-477.

Gauthier, G., and Albandakis, N., 1991. Minerals from the Seriphos skarn, Greece.Miner. Record, 22(4), 303-308.

Henjes-Kunst, F., and Kreuzer, H., 1982. Isotopic dating of Pre-Alpidic rocks from the Island of Ios (Cyclades, Greece). Contr. Miner. Petr. 80, 245-253.

Himmerkus, F., Reischmann, T., and Kostopoulos, D., K., 2006. Late Proterozoic and Silurian basement units within the Servomacedonian Massif, northern Greece: the significance of terrane accretion in the Hellenides. In: Robertson A.H.F. and D. Mountrakis (eds), Tectonic development of the Eastern Mediterranean Region. Geol. Soc. London Special Publ., 260, pp. 35-50.

Iglseder, C., Grasemann B., Schneider, D.A., Petrakakis K., Miller, C., Klötzli, U.S., Thöni, M., Zámolyi, A., and Rambousek, C., 2009. I and S-type plutonism on Seriphos (W-Cyclades, Greece). Tectonophysics, 473, 69-83.

Jacobshagen, V., 1986. Geologie von Griechenland. Gebrüder Borntraeger, Berlin, Stuttgart, 363pp.

Jolivet L, Rimmelé G, Oberhänsli R, Goffé B, Candan O (2004) Correlation of syn-orogenic tectonic and 
metamorphic events in the Cyclades, the Lycian nappes and the Menderes massif. Geodynamic implications. Bull Soc Géol Fr, 175, 217-238

Katzir, Y.,Avigad,D., Matthews, A., Garfunkel,Z., and Evans, B.W., 2000. Origin, HP/LT metamorphism and cooling of ophiolitic melanges in southern Evia (NW Cyclades), Greece. J. Metam. Geol., 18, 699-718.

Liati, A., 1986. Regional metamorphism and overprinting contact metamorphism of the Rhodope zone, near Xanthi (N. Greece). Petrology, Geochemistry, Geochronology: Unpub. Ph.D. thesis, Univ. Braunschweig. 186pp.

Lozios, S., 1993. Tectonic analysis of metamorphic formations of northeastern Attica. Unpubl. PhD thesis, Univ. Athens, 299pp. (in Greek)

Maneta, V., (2007) Quartz in Greece: Crystal forms and environment of formation. Unpubl. Diploma thesis, Univ. Athens, 149pp. (in Greek)

Mastrakas, N., 2006. Tinos pluton and associated skarn formations. Unpubl. PhD thesis, Univ. Patras, 227pp.

Melfos, V., 2005. Study of fluid inclusions in amethysts from areas of Macedonia and Thrace: Sapes, Soufli, Nevrokopi. 2nd Congress of the Economic Geology Committee, Mineralogy \& Petrology (GSG), Thessaloniki, October 2005, 219-228. (in Greek)

Melfos, V., Vavelidis, M., Christofides, G., and Seidel, E., 2002. Origin and evolution of the Tertiary Maronia porphyry copper-molybdenum deposit, Thrace, Greece. Mineral. Deposita 37, 648-668.

Mposkos, E., and Krohe, A., 2001. Structural evolution and exhumation history of the Rhodope UHP-HP metamorphic province (Northern Greece). Bull. Geol. Soc. Greece, 34, 75-82.

Papanikolaou, D., and Panagopoulos, A., 1981. On the structural style of southern Rhodope. Geol. Balc. 11, 13-22.

Pe-Piper, G., and Piper, D.J.W., 2002, The Igneous rocks of Greece. The anatomy of an orogene - Gebruder Borntraeger, 30: 573pp.

Reischmann, T. and Kostopoulos, D. 2007. Terrane accretion in the Internal Hellenides. Geophysical Reaserch abtracts, 9, 05337.

Rykart, R., 1995. Quarz-Monographie, Ott Verlag Thun, 461pp.

Salemink, J., 1980. On the Geology and Petrology of Serifos island (Cyclades, Greece). Ann. Geol. Pays Hell., 30, 342-365, Utrecht, Nederlands.

Shaked Y., Avigad D., and Garfunkel, Z., 2000. Alpine high-pressure metamorphism at the Almyropotamos window (southern Evia, Greece). Geol. Mag., 137, 367-380.

Tsolakos, A., Voudouris, P., and Papanikitas,A., 2008. Kristallklüfte in Attika and auf Euböa. Bergkristall, Amethyst und Rauchquarz aus Griechenland. Lapis, 5. 36-39.

Voudouris, P., 2005. The minerals of Eastern Macedonia-Thrace: Geological setting and the potential of geoconservation. GSG Congress, Samothraki, Bull. Geol. Soc. Greece 37, 62-77. (in Greek)

Voudouris, P., and Katerinopoulos, A., 2004. New occurences of mineral megacrysts in Tertiary magmatic-hydrothermal and epithermal environments in Greece. Documenta Naturae, 151, 1-21.

Voudouris, P., Katerinopoulos, A., and Melfos, V., 2004a. Alpine-type fissure minerals in Greece, Documenta Naturae, 151, 23-45.

Voudouris, V., Tsolakos, A., Papanikitas, A., and Solomos, C., 2004b. Nicht nur Micromounts. Neufunde aus Lavrion 2003. Lapis 4, 13-15.

Voudouris, P., Katerinopoulos, A., Christofalou, F., and Kassimi, G., 2007. Serifos island, Aegean Sea/Greece: a worldwide unique mineralogical and petrological geotope. ProGeo News, 1, 7-8.

Wawrzenitz, N., and Krohe, A., 1998, Exhumation and doming of the Thassos metamorphic core complex (S Rhodope, Greece): structural and geochronological contrains. Tectonophysics, 285, 301-332. 